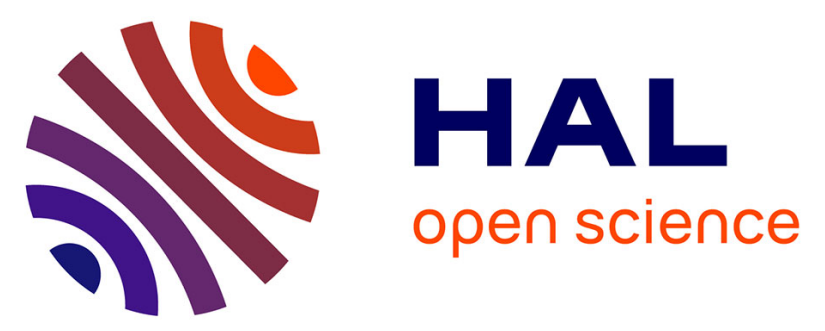

\title{
STRUCTURAL AND PHASE CHANGES IN HIGH-TEMPERATURE SUPERCONDUCTING CERAMICS DUE TO LASER RADIATION
}

\author{
A. Stepanenko, A. Alifanov, N. Rumak, T. Khatko, A. Tomchenko, V. Khatko
}

\section{- To cite this version:}

A. Stepanenko, A. Alifanov, N. Rumak, T. Khatko, A. Tomchenko, et al.. STRUCTURAL AND PHASE CHANGES IN HIGH-TEMPERATURE SUPERCONDUCTING CERAMICS DUE TO LASER RADIATION. Journal de Physique IV Proceedings, 1991, 01 (C7), pp.C7-143-C7-143. 10.1051/jp4:1991739 . jpa-00250978

\section{HAL Id: jpa-00250978 https://hal.science/jpa-00250978}

Submitted on 1 Jan 1991

HAL is a multi-disciplinary open access archive for the deposit and dissemination of scientific research documents, whether they are published or not. The documents may come from teaching and research institutions in France or abroad, or from public or private research centers.
L'archive ouverte pluridisciplinaire HAL, est destinée au dépôt et à la diffusion de documents scientifiques de niveau recherche, publiés ou non, émanant des établissements d'enseignement et de recherche français ou étrangers, des laboratoires publics ou privés. 


\title{
STRUCTURAL AND PHASE CHANGES IN HIGH-TEMPERATURE SUPERCONDUCTING CERAMICS DUE TO LASER RADIATION
}

\author{
A.V. STEPANENKO, A.V. ALIFANOV, N.V. RUMAK, T.N. KHATKO, A.A. TOMCHENKO and \\ V.V. KHATKO \\ Physical and Engineering Institute of Academy of Sciences of the BSSR, Zhodinskaya 4, \\ Minsk SU 220730, USSR
}

The present paper deals with investigation of the mechanism of changing a phase composition and a surface structure of targets made of high-temperature superconducting $\mathrm{Y}-\mathrm{Ba}-\mathrm{Cu}-\mathrm{O}-\mathrm{base}$ ceramics after impulse laser annealing $(\tau=1-6 \mu \mathrm{s}$ and $25 \mathrm{~ns}, \lambda=1.06$ and $0.7 \mu \mathrm{m})$. A density of radiation power, $q$, varied from $10^{4}$ to $10^{8} \mathrm{~W} \cdot \mathrm{cm}^{-2}$. Bearing in mind that at high temperatures thermochemical and thermodiffusional processes proceed at a target surface, air, oxygen and liquid nitrogen were taken as chemically active surrounding media. As samples, use was made of superconducting tablets moulded from the powder $\mathrm{YBa}_{2} \mathrm{Cu}_{3} \mathrm{O}_{7-x}$ manufactured according to the sol-gel fabrication route or by a solidphase synthesis and of the powder-base films deposited onto alumina ceramic substrates by a stenciling technique. A transition temperature of samples to a superconducting state found by $a$ change in their magnetic susceptibility depended on the method of manufacturing the original material and was equal to $85 \mathrm{~K}$ (the sol-gel technique) and to $97 \mathrm{~K}$ (the solid-phase synthesis). A phase composition and a surface structure of targets before and after laser radiation were studied by the X-ray diffraction method and metallographic examination. A spectral composition of plasma jets above a plasma action zone was examined by a quartz spectrograph.

Laser annealing allowed in some cases the improvement of surface quality, pore curing and stabilization of a high-temperature superconducting phase. 